\title{
X-ray Absorption Near Edge (XANES) Studies of Cu-Ni Ferrites
}

\author{
P. Sharma ${ }^{1}$, Ashutosh Mishra $^{2}$, Rashmi kame $^{3 *}$ \\ ${ }^{1}$ Dept. of Physics, Holkar Science College (Devi Ahilya University), Indore, India \\ ${ }^{2}$ School of Physics, Devi Ahilya University, Indore, India \\ ${ }^{3 *}$ School of Physics, Devi Ahilya University, Indore, India \\ *Corresponding Author: rashmikame23@gmail.com
}

Available online at: www.isroset.org

Receive $16^{\text {th }}$ Aug 2017, Revised 28 ${ }^{\text {th }}$ Aug 2017, Accepted 22 $2^{\text {th }}$ Sep 2017, Online $30^{\text {th }}$ Oct 2017

\begin{abstract}
Synthesis of Copper complexes $\left(\mathrm{Ni}_{1-\mathrm{x}} \mathrm{Cu}_{\mathrm{x}} \mathrm{Fe}_{2} \mathrm{O}_{4}\right)$ by the solid root method. XANES spectra have been recorded at the K-edge of $\mathrm{Cu}$ using the dispersive beam line at $2.5 \mathrm{GeV}$ Indus-2 synchrotron radiation source RRCAT(Raja Ramanna Centre for Advance Technology ), Indore, India. All the samples have been studied in powder form. From the $\mathrm{Ni}_{(1-\mathrm{x})} \mathrm{Cu}_{(\mathrm{x})} \mathrm{Fe}_{2} \mathrm{O}_{4}$ experimental measurements, the energy of the $\mathrm{K}$-absorption edge $\left(\mathrm{E}_{\mathrm{k}}\right)$,chemical $\operatorname{shift}\left(\Delta \mathrm{E}_{\mathrm{k}}\right)$, shift of the principal absorption $\operatorname{maxima}\left(\mathrm{E}_{\mathrm{A}}\right)$,edge widths $\left(\mathrm{E}_{\mathrm{w}}\right)$ percentage Covalency, and effective nuclear charge (ENC) in these complexes have been estimated.
\end{abstract}

Keywords- XANES, Athena, Hephaestus.

\section{INTRODUCTION}

Ferrites are usually nonconductive ferromagnetic compounds derived from oxides such as hematite $\left(\mathrm{Fe}_{2} \mathrm{O}_{3}\right)$ or magnetite $\left(\mathrm{Fe}_{2} \mathrm{O}_{4}\right)$ as well as oxide of the other metals[1].Cu-Ni Ferrites have gained technological important due to their high electrical resistivity ,low eddy current and low dielectric loss These material are extensively used in microwave device ,computer memory chips, magnetic recording media ,transformer cores, rod antennas etc.[2-5].XANES is strongly sensitive to formed oxidation state and coordination chemistry of the absorbing atom [6].

\section{EXPERIMENTAL}

Particles of the $\mathrm{Ni}_{1-\mathrm{x}} \mathrm{Cu}_{\mathrm{x}} \mathrm{Fe}_{2} \mathrm{O}_{4}$ with $\mathrm{x}$ (gm) varying from $\mathrm{x}=0.05$ to 0.25 were prepared by solid root method at room temperature.After weighing grind 8 to 9 hours the sample and powders were sintered at $2-2: 30$ hours at $550^{\circ} \mathrm{c}$ [7]. The $\mathrm{X}$-ray absorption spectra have been recorded using synchrotron radiation source .The X- ray spectroscopy setup is available at Raja Ramanna Centre for Advanced Technology (RRCAT) and is called beam line.

\section{RESULTS AND DISCUSSION}

The shift of the K-absorption edge of doping copper in the sample with respect to iron that of metal have been determine according to the chemical shift $\Delta$ Ek. In the present studies Kabsorption edge of cu was found to shift to the higher energy state, means chemical shift is positive .The chemical shift values obtained from absorption of ferrites samples are 5.4,6.4,7.4,8.2, 9.8 which suggest that $\mathrm{Cu}$ having +2 oxidation state in these types of ferrites. The chemical shift in the $\mathrm{X}$-ray absorption spectra is defined as the energy shift of the absorption edge of metal in a complex to the position in the metallic state [8]. The chemical shift is given by- $\Delta \mathrm{E}=$ Ek (Complex) -Ek (Metal), where E (Complex) = the energy position of the edge of a compound, and $\mathrm{E}$ (Metal) = the energy position of the edge of metal[9].

\section{CONCLUSION}

In $\mathrm{Cu}-\mathrm{Ni}$ ferrites, the Chemical shift values obtained from XANES spectra suggest that $\mathrm{Cu}$ is present in +2 oxidation state in these types of ferrites[10]. The values of XANES data of k- absorption edge reported in table - 1 and XANES graph of copper doped (Ni1-xCuxFe2O4) complexes shown in figure-1.The value of Ek, EA, Shift of principal absorption maxima, Edge Width, and ENC also shown in table 1.

\section{REFERENCES}

[1] A. Mishra, S.Ninama, P. Sharma, N. Soni and R. Awate, "A newly Synthesis and characterization of metal complexes of 3-(Nphenyl) thiourea- pentanone-2 as ligand", Journal of Physics: 
Conference Series, 365, ( 2012) International Conference on Recent Trends in Physics (ICRTP2012)

[2] P K Malviya, P Sharma and A. Mishra, "XRD and X -ray, $K$ Absorption Near Edge Studies of Cobalt, Nickel Ferrites", International Journal of Scientific Research in Physics and Applied Sciences, Vol.2, Issue.1, pp.1-4, 2014.

[3] G. Sathishkumar, C. Venkataraju and K.Sivakumar, "Synthesis, Structural and Dielectric Studies of Nickel Substituted CobaltZinc Ferrite," Materials Sciences and Applications, Vol. 1 No. $1,2010$.

[4] S. Gubbala, H. Nathani, K. Koziol and R. D. K. Misra, "Magnetic Properties of Nanocrystalline Ni-Zn, Zn-Mn, and Ni-Mn Ferrites Synthesized by Reverse Micelle Technique," Physica B Condensed Matter, Vol. 348, No. 1-4, 2004

[5] C. Suryanarayana and M. G. Norton, "X-Ray Diffraction a Practical Approach,” Plenum Press, New York, 1998.
[6] P K Malviya, P Sharma and A. Mishra, "Extended X-ray, $K$ absorption Fine Structural Studies of Cobalt, Nickel Ferrites", International Journal of Scientific Research in Physics and Applied Sciences, Vol.1, Issue.1, pp.1-9, 2013.

[7] P. K. Sharma, A. Mishra, R. Kame,V. Malviya and P .K. Malviya, Frontiers of Physics and Plasma Science IOP Publishing IOP Conf. Series: Journal of Physics: Conf. Series, 2017.

[8] P.K.Malviya, Varsha Malviya , Rashmi Kame, "X-Ray $K$ Absorption Near Edge Structural Studies of Mixed Ligand Copper II With Pyridine-2-Carboxamide and Amino Acids", International Journal of Scientific Research in Physics and Applied Sciences, Vol.5, Issue.1, pp.1-7, 2017.

[9] P.K.Malviya, Varsha Malviya and Rashmi Kame, "X-Ray $K$ Absorption Near Edge Structural Studies of Mixed Ligand Copper II With Pyridine-2-Carboxamide and Amino Acids", International Journal of Scientific Research in Physics and Applied Sciences, Vol.5, Issue.1, pp.1-7, 2017

Table-1 XANES data for the K- absorption near edge of Copper complexes

\begin{tabular}{|l|c|c|l|l|l|l|l|}
\hline Complexes & $\begin{array}{c}\mathrm{E}_{\mathrm{K}^{-}} \\
\text {Edge } \\
(\mathrm{eV})\end{array}$ & $\begin{array}{c}\mathrm{E}_{\mathrm{A}} \\
(\mathrm{eV})\end{array}$ & $\begin{array}{c}\text { Chemical } \\
\text { Shift (eV) }\end{array}$ & $\begin{array}{c}\text { Shift of principal } \\
\text { absorption } \\
\text { maxima(eV) }\end{array}$ & $\begin{array}{c}\text { Edge } \\
\text { Width } \\
(\mathrm{eV})\end{array}$ & $\begin{array}{c}\text { ENC } \\
\text { Electron/ } \\
\text { Atom }\end{array}$ & $\begin{array}{c}\text { Percentage } \\
\text { Covalancy }\end{array}$ \\
\hline $\mathrm{Ni}_{0.95} \mathrm{Cu}_{0.05} \mathrm{Fe}_{2} \mathrm{O}_{4}$ & 8984.4 & 8991.3 & 5.4 & 12.3 & 6.9 & 0.37 & 23.79 \\
\hline $\mathrm{Ni}_{0.90} \mathrm{Cu}_{0.10} \mathrm{Fe}_{2} \mathrm{O}_{4}$ & 8985.4 & 8992.7 & 6.4 & 13.7 & 7.3 & 0.44 & 25.17 \\
\hline $\mathrm{Ni}_{0.85} \mathrm{Cu}_{0.15} \mathrm{Fe}_{2} \mathrm{O}_{4}$ & 8986.4 & 8993.3 & 7.4 & 14.3 & 6.9 & 0.51 & 23.79 \\
\hline $\mathrm{Ni}_{0.80} \mathrm{Cu}_{0.20} \mathrm{Fe}_{2} \mathrm{O}_{4}$ & 8987.2 & 8994.6 & 8.2 & 15.6 & 7.4 & 0.56 & 25.51 \\
\hline $\mathrm{Ni}_{0.75} \mathrm{Cu}_{0.25} \mathrm{Fe}_{2} \mathrm{O}_{4}$ & 8988.8 & 8995.7 & 9.8 & 16.7 & 6.9 & 0.67 & 23.79 \\
\hline
\end{tabular}

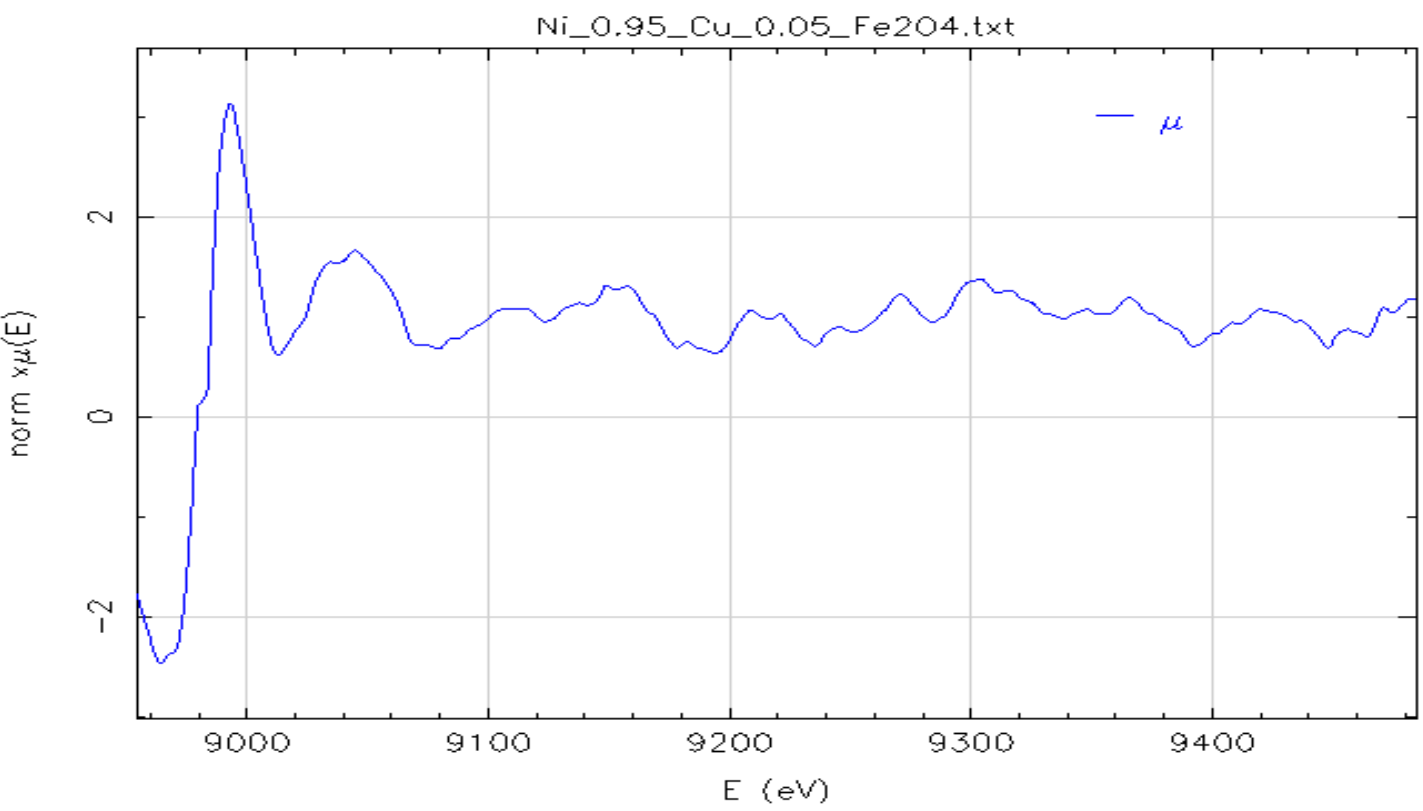



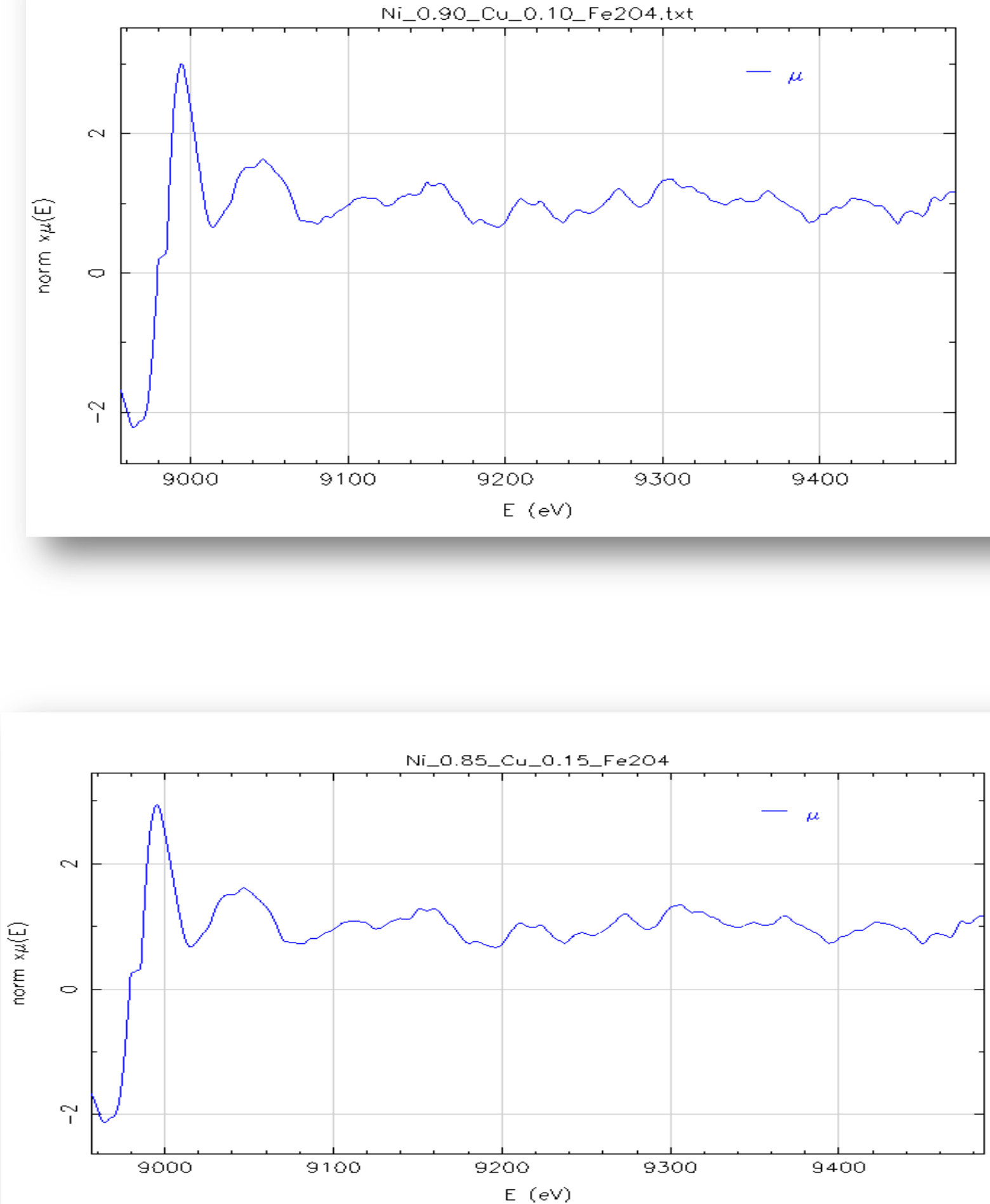

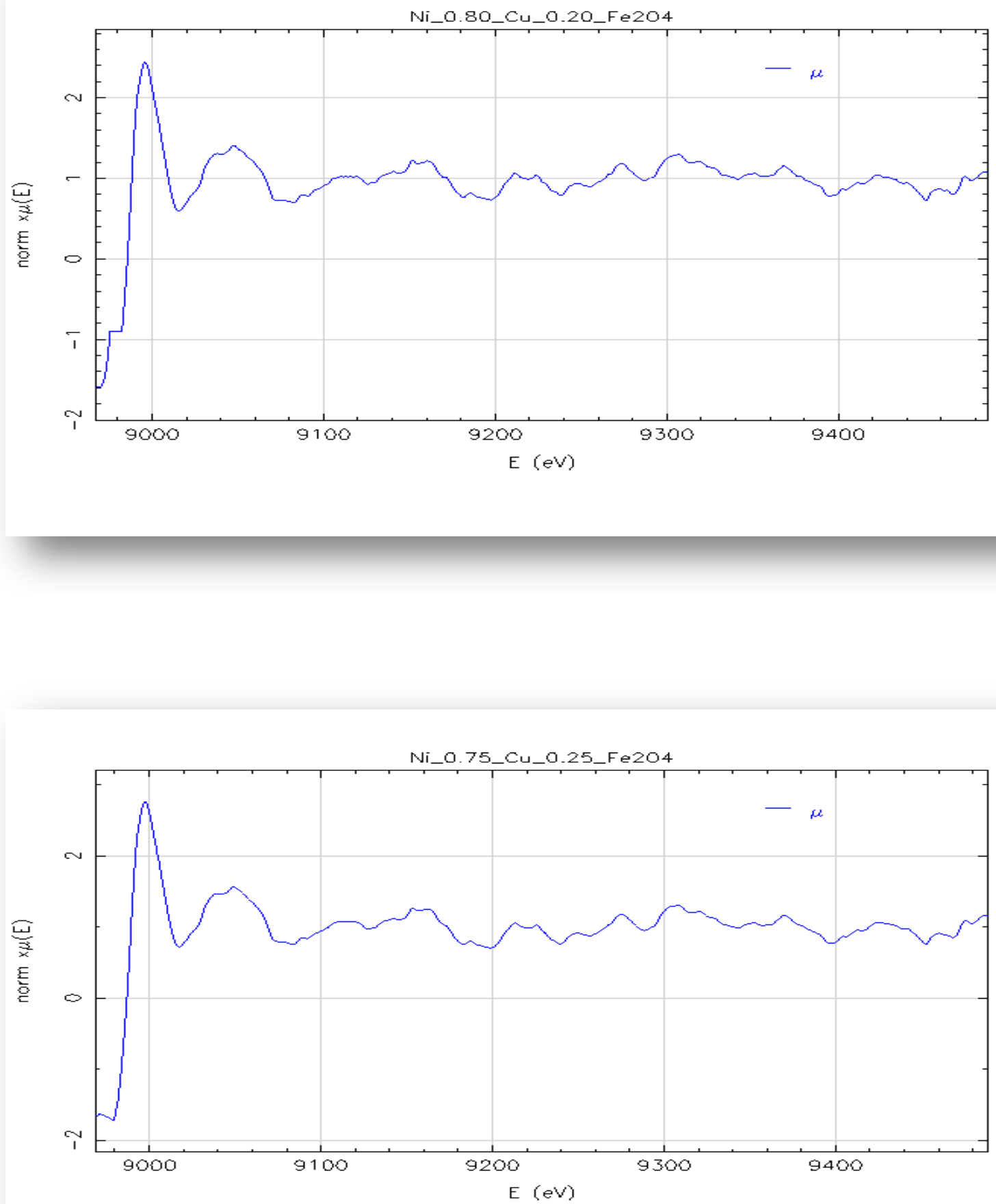

Fig. 1 XANES graphs of copper doped $\left(\mathrm{Ni}_{1-\mathrm{x}} \mathrm{Cu}_{\mathrm{x}} \mathrm{Fe}_{2} \mathrm{O}_{4}\right)$ complexes. 